\title{
Association between arbuscular mycorrhizal fungi and Pratylenchus brachyurus in maize crop
}

\author{
Olivia Diulen Costa Brito ${ }^{1}$, Isabela Hernandes ${ }^{2}$, Júlio César Antunes Ferreira ${ }^{3}$, Michelly Ragazzi Cardoso ${ }^{4}$, \\ Odair Alberton ${ }^{5}$, and Claudia Regina Dias-Arieira ${ }^{*}$ \\ ${ }^{1}$ Universidade Estadual do Oeste do Paraná, Pós Graduação em Agronomia, Estrada Pernambuco 1777, Marechal Cândido Rondon, \\ Paraná, Brasil. *Corresponding author (odc.brito@gmail.com). \\ ${ }^{2}$ Universidade Estadual de Maringá, Pós Graduação em Agronomia, Avenida Colombo 5790, Maringá, Paraná, Brasil. \\ ${ }^{3}$ Universidade Paulista "Júlio Mesquita Filho", Campus de Botucatu, Pós Graduação em Agronomia, Fazenda Lageado, Avenida \\ Universidade 3780, Botucatu, São Paulo, Brasil. \\ ${ }^{4}$ Universidade Estadual de Maringá, Pós Graduação em Ciências Agrárias, Estrada da Paca, Umuarama, Paraná, Brasil. \\ ${ }^{5}$ Universidade Paranaense Programa de Pós-Graduação Stricto Sensu, Praça Mascarenhas de Moraes 4282, Umuarama, Paraná, Brasil.
}

Received: 6 June 2018; Accepted: 20 October 2018; doi:10.4067/S0718-58392018000400521

\begin{abstract}
Maize (Zea mays L.) is one crop of major relevance in Brazil; however, nematodes are limiting factors in maize growth and productivity due to the difficulty to control them. Studies point out that arbuscular mycorrhizal fungi (AMF) increase plant tolerance to nematodes. Thus, the aim of this study was to assess the association between AMFs and Pratylenchus brachyurus in maize growth. Six AMF species (Rhizophagus clarus, Claroideoglomus etunicatum, Gigaspora rosea, $G$. margarita, Scutellospora calospora, S. heterogama), as well as a control treatment free of mycorrhizae, were assessed under two different nematode inoculum conditions (presence and absence). Plants were collected and analyzed $60 \mathrm{~d}$ after inoculation. The nematode population was higher in the treatments inoculated with AMFs. On the other hand, just the plants inoculated with $R$. clarus did not present improved development in comparison to the control. Nematodes increased AMF spore density, but despite the fact that AMFs have presented different root colonization capacity (ranging from 2.3\% to $95.0 \%$ ), such capacity was not affected by the nematodes.
\end{abstract}

Key words: Management, mycorrhizal, root-lesion nematode, Zea mays.

\section{INTRODUCTION}

Brazil is the third greatest maize (Zea mays L.) producer and the second exporter in the world (DEAGRO/FIESP, 2018). Maize is one of the crops of major economic relevance in the country, despite being one of the main alternatives for crop rotation and succession in soybean plantation areas (Inomoto, 2008). There is a whole variety of production systems, which go from high technological levels adapted to the national and international markets, to the total absence of technology in subsistence productions.

However, maize is severely attacked by nematodes, mainly by those belonging to genus Pratylenchus Filipjev, which is considered one of the most important for this crop. The main species causing the worse losses in maize crops are Pratylenchus zeae Graham and P. brachyurus (Godfrey) Filipjev \& Schuurmans Stekhoven (Goulart, 2008). The fact that maize is a crop used for soybean succession - soybean is also a good P. brachyurus host - in association with no-tillage, which keeps high soil humidity and enables root permanence in the field, promotes constant nematode population increase in the area and impairs a better control (Inomoto, 2008).

The main methods to manage this nematode are crop residue destruction, crop rotation, use of cultivars or resistant hybrids, and chemical and biological control. Biological control stands out as a feasible management alternative against 
nematodes, because it minimizes environmental damages and may present good cost-benefit ratio in comparison to chemical treatments (Coimbra and Campos, 2005).

Different fungi and bacteria have been assessed for nematode biological control purposes (Sharma and Sharma, 2017). The arbuscular mycorrhizal fungi (AMFs) stand out among these species, they are distributed in different ecosystems, and associate themselves with $90 \%$ of the plant species (Smith and Read, 2008; Schouteden et al., 2015). They increase climatic stress tolerance, generate plant resistance against pathogens and reduce costs with fertilizers, since these fungi enlarge the nutrient-absorption area and allow the access to less-available nutrients or to nutrients presenting low mobility in the soil (Smith and Read, 2008; Schouteden et al., 2015).

Studies have been reporting that AMFs can increase plant tolerance to Pratylenchus species in some crops (Talavera et al., 2001; Elsen et al., 2008; Vos et al., 2012). However, the species P. brachyurus imposes research restrictions, because there are reports about nematode-tolerance increase in cotton crops colonized by AMF Gigaspora margarita Becker and Hall (Hussey and Roncadori, 1978).

Because of lack of information about the relation between AMF and P. brachyurus, the aim of the present study was to assess the association between AMFs and P. brachyurus in maize for nematode control purposes. Moreover, it aimed at studying the colonization capacity of mycorrhizal and plant growth.

\section{MATERIALS AND METHODS}

The experiment was conducted in greenhouse ( $23^{\circ} 47^{\prime} 28.46^{\prime \prime} \mathrm{S}, 53^{\circ} 15^{\prime} 23.46^{\prime \prime} \mathrm{W} ; 430 \mathrm{~m}$ a.s.1.) The completely randomized design was adopted at factorial scheme $7 \times 2$, wherein seven is the number of treatments using AMFs (six AMFs + AMF free control) and two is the number of nematode inoculum conditions, namely: presence or absence of nematodes, with eight replicates for each treatment. The experiment was conducted between November 2014 and January 2015, when the mean minimum and maximum temperatures were 20.8 and $31.2^{\circ} \mathrm{C}$, respectively.

Firstly, the sandy soil (LVd19 - Dystrophic Red Latosol) was collected and doubly autoclaved at $120{ }^{\circ} \mathrm{C}$ for $2 \mathrm{~h}$, with one day interval between autoclaving. Each pot was filled with $3 \mathrm{~L}$ soil; the autoclaved soil covered $3 / 5$ of the pots. Subsequently, $1 / 5$ of soil inoculum, containing approximately 250 spores of each AMF treatment, was added in the pots, followed by $1 / 5$ of autoclaved soil. Nematode-free pots were used as control.

The AMF Rhizophagus clarus (Nicolson and Schenck) Walker and Schüssler, Claroideoglomus etunicatum (Becker and Gerd.) Walker and Schüssler, Gigaspora rosea Nicolson and Schenck, Gigaspora margarita Becker and Hall, Scutellospora heterogama (Nicolson and Gerd.) Walker and Sanders, and Scutellospora calospora (Nicolson and Gerd.) Walker and Sanders were selected from a well-established Glomales bank at UNIPAR (Paranaense University, Paraná State, Brazil) accessions number 10, 11, 12, 08, 06, and 04, respectively (Rosseto et al., 2012; Urcoviche et al., 2015).

All AMFs were previously multiplied in maize growing in pots containing $10 \mathrm{~kg}$ sterile soil. The species of AMF prior to inoculation were confirmed based on spore morphology, and the same when assessing spore production post-test. These six AMF species were selected due the diversity and importance in Brazilian soils and crops (Rosseto et al., 2012; Urcoviche et al., 2014); as reported by Veresoglou and Rillig (2012), AMF identity also is crucial for pathogen protection as nematodes.

Four maize seeds 'IPR 114' were sown in each pot, at the same day the soil was prepared. Thinning was performed 6 $\mathrm{d}$ after germination, and one seedling was kept in each pot. In half pots, the seedlings were inoculated with a population of 1000 P. brachyurus specimens in $4 \mathrm{~mL}$ solution, which was deposed in three holes, opened in the soil around the plant stem. The inoculum derived from a pure nematode population kept in maize, in greenhouse, during 2-mo. The specimens were extracted from roots through process performed in a blender, followed by centrifugation in sucrose solution (Coolen and D'Herde, 1972). The Peters' slide was used for nematode counting in optical microscope (100X).

Plants were collected 2-mo after inoculation and their shoots were separated from their root systems. The height and shoot fresh and dry weight were recorded. The dry weight was obtained after drying in forced air flow oven, at $65^{\circ} \mathrm{C}$, until constant weight. The root system was carefully washed, and root fresh weight was subsequently recorded; $2 \mathrm{~g}$ root were separated from the median region to assess AMF root colonization. The rest of the root system was subjected to extraction and to P. brachyurus evaluation per root system, through extraction and counting, as aforementioned. The total number of nematodes was divided by the root weight in order to determine the number of nematodes $\mathrm{g}^{-1}$ root. 
The collected root portion was cut in pieces of approximately $1 \mathrm{~cm}$ to set the root colonization by AMFs. The root pieces were inked through the method proposed by Phillips and Hayman (1970). Then, they were preserved in lacto-glycerol until the moment to prepare the slides. The analysis applied to the percentage of colonized segments was performed using microscopy slides. One hundred segments were analyzed per replicate, in each treatment (Giovannetti and Mosse, 1980), in stereoscopic microscope (100X) to identify the areas colonized by hypha, arbuscules and vesicles. The total root colonization by AMFs was transformed for data normalization through the equation: Total colonization $\left(\operatorname{Col}_{t}\right)=$ $(\operatorname{ArcSin} \sqrt{C o l}(\%) / 100)(180 / \pi)$, where $\operatorname{Col}_{t}$ is the total root colonization, ArcSin is the inverse of sine, $\pi$ is $\mathrm{Pi}$.

The total of $100 \mathrm{~cm}^{3}$ soil were removed from the rhizosphere region of each pot. The removed soil was subjected to nematode extraction process (Jenkins, 1964) and samples were assessed according to the previously mentioned procedure. Moreover, $10 \mathrm{~g}$ rhizosphere soil were also collected to AMF spore extraction, which was carried out according to the wet sieving method (Gerdemann and Nicolson, 1963). The samples were subjected to centrifugation in water (3000 rpm $3 \mathrm{~min}^{-1}$ ) and in 50\% sucrose (2000 rpm $2 \mathrm{~min}^{-1}$ ) for counting; supernatant was once more wet sieved through $0.053 \mathrm{~mm}$ mesh. The extracted spores were preserved in $0.05 \%$ azide-sodium solution, until the time to perform the counting - when the samples were transferred to Petri dishes and counted in stereoscope microscope (40X).

The variance normality of data was assessed through Shapiro Wilk test, and through transformation by $\sqrt{ }(x+0.5)$ whenever necessary, except for colonization by AMFs. The collected data were subjected to ANOVA at 5\% error probability. The mycorrhizal and nematode factors were compared to each other through the Scott-Knott and Bonferrini's $t$ tests, respectively, at the same significance level, in the Sis Var software (Ferreira, 2014).

\section{RESULTS}

All the assessed nematological variables presented larger numbers in plants inoculated with AMFs in comparison to noninoculated plants. The highest values of P. brachyurus root system and total nematodes were recorded in plants inoculated with S. heterogama, R. clarus and C. etunicatum (Table 1).

The Mycorrhizal $\times$ Nematode interaction was significant $(\mathrm{p}<0.05)$ in the variables shoot height and fresh weight. Mycorrhizal disruption for the nematode factor was significant in plants free from $P$. brachyurus in both variables (Table 2). Accordingly, the greatest development recorded for these variables (shoot dry weight, SDW) was observed in nematode-free plants when they were inoculated with S. heterogama, C. etunicatum, S. calospora and G. rosea. The presence of nematodes increased shoot height and fresh weight in the AMF-free control and in plants inoculated with $G$. margarita. The mycorrhizal factor in SDW was significant, but there was no interaction between factors. All other AMFs accept for $R$. clarus, which did not differ from the control, promoted SDW increase by $34 \%$ to $67 \%$ (Table 2).

Mycorrhizae and interaction between factors did not change root weight, but this variable was just affected by the presence or absence of nematodes. Thus, plants colonized by nematodes presented root weight $(21.48 \mathrm{~g})$ greater than nematode-free plants (18.02 g) (data not shown).

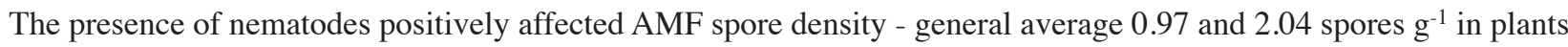
with and without nematode, respectively. The interaction between factors was also significant $(\mathrm{p}<0.05)$ for spore density. Greater spore density was recorded in maize inoculated with $R$. clarus when the mycorrhizal factor was assessed within the

Table 1. Pratylenchus brachyurus $(\mathrm{Pb})$ per root system, per root gram, and total population in maize subjected to different treatments using mycorrhizae.

\begin{tabular}{lccc}
\hline Treatments & $\mathrm{Pb} /$ root system & $\mathrm{Pb} \mathrm{g}^{-1}$ root & $\mathrm{Pb}$ total \\
\hline Scutellospora heterogama & $21925 \mathrm{a}$ & $1230 \mathrm{a}$ & $22337 \mathrm{a}$ \\
Rhizophagus clarus & $21345 \mathrm{a}$ & $1341 \mathrm{a}$ & $21795 \mathrm{a}$ \\
Claroideoglomus etunicatum & $14150 \mathrm{a}$ & $665 \mathrm{a}$ & $14840 \mathrm{a}$ \\
S. calospora & $10085 \mathrm{~b}$ & $557 \mathrm{a}$ & $10127 \mathrm{~b}$ \\
Gigaspora margarita & $10012 \mathrm{~b}$ & $621 \mathrm{a}$ & $11047 \mathrm{~b}$ \\
G. rosea & $9712 \mathrm{~b}$ & $710 \mathrm{a}$ & $9910 \mathrm{~b}$ \\
Control & $2525 \mathrm{c}$ & $123 \mathrm{~b}$ & $2847 \mathrm{c}$ \\
\hline CV, $\%$ & 24.53 & 31.76 & 23.73 \\
\hline
\end{tabular}

Means followed by the same letter in the columns did not differ from each other, according to the Scott-Knott test. CV: Coefficient of variation. 
Table 2. Shoot height and fresh weight in mycorrhized plants with and without nematodes and general mean shoot dry weight of maize subjected to different treatments using mycorrhizae.

\begin{tabular}{|c|c|c|c|c|c|}
\hline \multirow[b]{2}{*}{ Treatments } & \multicolumn{2}{|c|}{ Height } & \multicolumn{2}{|c|}{ Shoot fresh weight } & \multirow{2}{*}{$\begin{array}{c}\begin{array}{c}\text { Shoot dry } \\
\text { weight }\end{array} \\
\begin{array}{c}\text { General } \\
\text { mean }\end{array}\end{array}$} \\
\hline & $\begin{array}{l}\text { Without } \\
\text { nematode }\end{array}$ & $\begin{array}{c}\text { With } \\
\text { nematode }\end{array}$ & $\begin{array}{c}\text { Without } \\
\text { nematode }\end{array}$ & $\begin{array}{c}\text { With } \\
\text { nematode }\end{array}$ & \\
\hline & \multicolumn{2}{|c|}{$\mathrm{cm}$} & \multicolumn{2}{|c|}{$-\mathrm{g}$} & g \\
\hline Scutellospora heterogama & $67.30 \mathrm{aA}$ & $70.10 \mathrm{aA}$ & $19.18 \mathrm{aA}$ & $25.36 \mathrm{aA}$ & $4.32 \mathrm{a}$ \\
\hline Rhizophagus clarus & $58.40 \mathrm{bA}$ & $65.30 \mathrm{aA}$ & $13.34 \mathrm{bA}$ & $18.76 \mathrm{aA}$ & $2.57 \mathrm{~b}$ \\
\hline Claroideoglomus etunicatum & $69.30 \mathrm{aA}$ & $76.30 \mathrm{aA}$ & $22.09 \mathrm{aA}$ & $31.11 \mathrm{aA}$ & $4.60 \mathrm{a}$ \\
\hline S. calospora & $67.60 \mathrm{aA}$ & $66.80 \mathrm{aA}$ & $22.59 \mathrm{aA}$ & $22.42 \mathrm{aA}$ & $4.33 \mathrm{a}$ \\
\hline Gigaspora margarita & $58.40 \mathrm{bB}$ & $71.10 \mathrm{aA}$ & $14.11 \mathrm{bB}$ & $24.84 \mathrm{aA}$ & $3.68 \mathrm{a}$ \\
\hline G. rosea & $65.20 \mathrm{aA}$ & $66.80 \mathrm{aA}$ & $20.00 \mathrm{aA}$ & $23.33 \mathrm{aA}$ & $3.93 a$ \\
\hline Control & $48.70 \mathrm{bB}$ & $72.20 \mathrm{aA}$ & $8.01 \mathrm{bB}$ & $25.50 \mathrm{aA}$ & $2.75 b$ \\
\hline $\mathrm{CV}, \%$ & \multicolumn{2}{|c|}{14.68} & \multicolumn{2}{|c|}{40.67} & 45.15 \\
\hline
\end{tabular}

Means followed by the same lower-case letter in the columns and by the same uppercase letters on the lines did not differ from each other, according to the Scott-Knott and Bonferroni- $t$ tests.

CV: Coefficient of variation.

Table 3. Spore density and root colonization by arbuscular mycorrhizal fungi in maize plants, with or without Pratylenchus brachyurus.

\begin{tabular}{|c|c|c|c|}
\hline \multirow[b]{2}{*}{ Treatments } & \multirow[b]{2}{*}{ With nematode } & \multirow[b]{2}{*}{ Without nematode } & \multirow{2}{*}{$\frac{\text { Colonization }}{\text { General mean }}$} \\
\hline & & & \\
\hline & \multicolumn{2}{|c|}{ Number spores $\mathrm{g}^{-1}$ dry soil } & $\%$ \\
\hline Scutellospora heterogama & $1.45 \mathrm{bA}$ & $0.47 \mathrm{bA}$ & $11.70 \mathrm{~b}$ \\
\hline Rhizophagus clarus & $7.09 \mathrm{aA}$ & $3.10 \mathrm{aB}$ & $95.20 \mathrm{a}$ \\
\hline Claroideoglomus etunicatum & $1.13 \mathrm{bA}$ & $1.27 \mathrm{bA}$ & $13.50 \mathrm{~b}$ \\
\hline S. calospora & $1.88 \mathrm{bA}$ & $0.90 \mathrm{bA}$ & $12.90 \mathrm{~b}$ \\
\hline Gigaspora margarita & $0.72 \mathrm{bA}$ & $0.49 \mathrm{bA}$ & $10.60 \mathrm{~b}$ \\
\hline G. rosea & $1.64 \mathrm{bA}$ & $0.60 \mathrm{bA}$ & $2.30 \mathrm{c}$ \\
\hline Control & $0.30 \mathrm{bA}$ & $0.00 \mathrm{bA}$ & $3.50 \mathrm{c}$ \\
\hline $\mathrm{CV}, \%$ & \multicolumn{2}{|c|}{82.33} & 39.44 \\
\hline
\end{tabular}

Means followed by the same lower-case letter in the columns and by the same uppercase letters on the lines did not differ from each other, according to the Scott-Knott and Bonferroni- $t$ tests. CV: Coefficient of variation.

nematode factor, whereas nematode disruption within mycorrhizae showed that plants treated with $R$. clarus containing nematodes presented spore density higher than plants without nematode inoculation.

The root colonization, in its turn, was affected by mycorrhizae regardless of the presence or absence of the nematode. All other treatments presented greater colonization, mainly plants colonized by $R$. clarus (95.20\%), except for G. rosea, which did not differ from the control (Table 3).

\section{DISCUSSION}

Regardless of the studied AMF species, $P$. brachyurus population increased in mycorrhized plants, and this result is different from reports in the literature (Vos et al., 2012; Veresoglou and Rillig, 2012; Baum et al., 2015; Schouteden et al., 2015). Studies have been pointing out that the best results for nematode management using mycorrhizae are recorded when AMFs are applied to the soil at least $30 \mathrm{~d}$ before sowing in comparison to the nematode. There are reports describing that colonization in some plants may happen within 2 to 4 wk (Alkan et al., 2006; Jansa et al., 2008). A well-succeeded colonization seems to be the requirement for effective nematode control (Pozo and Azcón-Aguilar, 2007).

However, this time advantage did not happen in agricultural soils in which nematodes and mycorrhizae are found and may also show the same competitive advantage (Schouteden et al., 2015). Moreover, results depend on a series of factors 
including AMF isolates, host plant species, pathogens in association with the plant species, and soil and environmental conditions (Whipps, 2004; Veresoglou and Rillig, 2012; Baum et al., 2015).

Overall, plants trigger a basal defense response called PTI (PAMP-triggered immunity, in which PAMP is pathogenassociated molecular pattern) in the interaction location when they are infected by pathogens; however, AMFs are capable of suppressing this initial defense response in order to allow colonization to take place (Bhargava and Nair, 2016). Plants colonized by AMFs accumulate high jasmonic acid (JA) levels (Nair et al., 2015). This acid antagonizes the salicylic acid (SA) signaling, which, in turn, plays an important role in PTI expression. However, the defense signaling via SA is suppressed by high JA concentrations (López-Ráez et al., 2010; Thaler et al., 2012), fact that may have favored the initial nematode penetration and increased the number of nematodes in mycorrhized plants. Such result may explain the large number of P. brachyurus in plants inoculated with S. heterogama, R. clarus and C. etunicatum, which have recorded the greatest root colonization.

The effects from the interaction between nematode and AMF, which is expressed by the host's response, can be classified as neutral when there are no evident changes in AMFs, hosts or in the nematode. These effects are positive when plant damages caused by pathogens are compensated by the AMF, and when the development and number of nematodes are suppressed. The effects are negative if AMF sporulation and/or plant development are suppressed and nematode reproduction increases (Hussey and Roncadori, 1982).

Interaction results in the present study can be classified as negative, since there was nematode-number increase and the mycorrhizal presence in plants inoculated with nematodes did not influence their growth. Similar results were recorded in other pathosystems wherein the AMF/Pratylenchus interaction did not stimulate plant growth (Calvet et al., 1995; Pinochet et al., 1998). Such response can happen because colonization by AMFs may generate high energy cost for plants and, in some cases, such cost cannot be compensated by further mycorrhization (Vos et al., 2012). However, it is worth highlighting that there are reports about mycorrhizae promoting growth in cotton plants infected by P. brachyurus (Hussey and Roncadori, 1978) and in carrot plants infected by P. penetrans (Cobb) Filipjev and Schuurmans Stekhoven (Talavera et al., 2001).

Despite the results of plants inoculated with nematodes, the positive effect of mycorrhizae on maize crop can be observed in some interactions. Thus, except for $R$. clarus, which did not differ from the control, all other AMFs led to plant growth. The AMFs presented different growth promotion results in their study, and G. margarita and R. clarus had worse performance than C. etunicatum. Such result derived from the benefits provided by AMFs, which are correlated with the combination between plant-fungus and edaphoclimatic conditions (Smith et al., 2004; Smith and Read, 2008; Baum et al., 2015). Thus, although AMFs are usually beneficial to plants, they can have negative action over the hosts (Smith and Read, 2008), therefore, mycorrhizae performance is not positively correlated with plant development (Ba et al., 2000). It explains the results recorded for R. clarus, which presented lower growth response than the other treatments; however, it was the AMF recording the greatest spore density and root colonization.

The plants with nematodes presented more root weight than plants without them, and it is commonly observed in infected hosts. However, plants develop natural defense mechanisms and face different changes when they are infected by nematodes. It is possible highlighting the hormonal metabolism among these changes, because it acts in the concentrations of auxins, cytokinins and ethylene (Faria et al., 2003; Stangarlin et al., 2011). Auxins and cytokinins regulate root growth; in case of stress, ethylene can act in root horizontal growth (Taiz and Zeiger, 2013). Accordingly, it is possible hypothesizing that plants generate new roots when they are infected by nematodes to suppress damages caused by the pathogen.

With regard to the variable "mycorrhizae", plants with nematodes presented greater sporulation than nematode-free plants, and it allows assuming that the competition between nematode and AMF may have stimulated AMF sporulation. Such fact may have occurred when plants were under stress (Smith et al., 2004; Smith and Read, 2008; Baum et al., 2015; Schouteden et al., 2015), and it may even have led to greater G. margarita sporulation, as it was reported for tomato plants inoculated with Meloidogyne javanica (Treub) Chitwood (Cofcewicz et al., 2001), Sharma and Sharma (2017) also reported physiological and biochemical changes in tomato inoculated with AMF against root-knot nematode, observing that plants treated with inoculation of AMF showed significantly enhanced plant growth and reduced nematode infection.

On the other hand, the presence or absence of nematodes did not influence mycorrhizal colonization, and this result goes against that found by Grümberg et al. (2015). As the nematode inoculation was performed $6 \mathrm{~d}$ after mycorrhizal 
inoculation, one can assume that the nematode did not influence the initial colonization by the fungus, since these organisms did not compete for infection and colonization sites in the first week. The other treatments presented greater root colonization among the studied AMFs, except for G. rosea, which did not differ from the control. Rhizophagus clarus presented the highest colonization average (95\%) and the best spore density per soil gram. These data were similar to those recorded for $R$. clarus under nematode presence (Grümberg et al., 2015).

\section{CONCLUSIONS}

The mechanisms involved in the interactions among mycorrhizae, nematodes and plants remain non-elucidated, mainly because they concern high complexity relations. However, the current study allowed concluding that there was no Pratylenchus brachyurus suppression in maize plants inoculated with different arbuscular mycorrhizal fungi (AMFs). Moreover, the AMFs showed different colonization indices in maize and some species were efficient in promoting maize development.

\section{REFERENCES}

Alkan, N., Gadkar, V., Yarden, O., and Kapulnik, Y. 2006. Analysis of quantitative interactions between two species of arbuscular mycorrhizal fungi, Glomus mosseae and G. intraradices, by real-time PCR. Applied and Environmental Microbiology 72:4192-4199. doi:10.1128/AEM.02889-05.

Ba, A.M., Plenchette, C., Danthu, P., Duponnois, R., and Guissou, T. 2000. Functional compatibility of two arbuscular mycorrhizae with thirteen fruit trees in Senegal. Agroforestry Systems 50:90-105. doi:10.1023/A:1006482904452.

Baum, C., El-Tohamy, W., and Gruda, N. 2015. Increasing the productivity and product quality of vegetable crops using arbuscular mycorrhizal fungi: A review. Scientia Horticulturae 187:131-141. doi.org/10.1016/j.scienta.2015.03.002.

Bhargava, S., and Nair, A. 2016. Mycorrhizae and the induction of resistance against biotic stress. p. 33-34. In Reunião Brasileira sobre Indução de Resistência em Plantas a Patógenos, Goiânia. 23-25 novembro 2016. Universidade Federal de Goiás (UFG) e Empresa Brasileira de Pesquisa Agropecuária (Embrapa), Goiás, Brasil.

Calvet, C., Pinochet, J., Camprubí, A., and Fernández, C. 1995. Increased tolerance to the root-lesion nematode Pratylenchus vulnus in mycorrhizal micropropagated BA-29 quince rootstock. Mycorrhiza 5:253-258. doi:10.1007/BF00204958.

Cofcewicz, E.T., Medeiros, C.A., Carneiro, R.M., and Pierobom, C.R. 2001. Interaction of arbuscular mycorrhizal fungi Glomus etunicatum and Gigaspora margarita and root-knot nematode Meloidogyne javanica in tomato. Fitopatologia Brasileira 26:65-70. doi:10.1590/S0100-41582001000100011.

Coimbra, J.L., and Campos, V.P. 2005. Effect of colony exudates and culture filtrates of actinomycetes on hatching, mobility and mortality of second stage juveniles of Meloidogyne javanica. Fitopatologia Brasileira 30:232-238. doi:10.1590/S0100-41582005000300003.

Coolen, W.A., and D'Herde, C.J. 1972. Method for the quantitative extraction of nematodes from plant tissue. 77 p. State Nematology and Entomology Research Station, Ghent, Belgium.

DEAGRO/FIESP. 2018. Safra mundial de milho 2018/19 - $1^{\circ}$ Levantamento do USDA. 1 p. Informativo DEAGRO de maio de 2018. Federação das Indústrias do Estado de São Paulo (FIESP), São Paulo, Brasil.

Elsen, A., Gervacio, D., Swennen, R., and De Waele, D. 2008. AMF-induced biocontrol against plant parasitic nematodes in Musa sp.: a systemic effect. Mycorrhiza 18:251-256. doi:0.1007/s00572-008-0173-6.

Faria, C.M.D.R., Salgado, S.M., Campos, H.D., Resende, M.L., Campos, V.P., e Coimbra, J.L. 2003. Mecanismos de ataque e defesa na interação nematóide-planta. Revisao Anual de Patologia de Plantas 11:373-410.

Ferreira, D.F. 2014. Sis Var: a guide for its Bootstrap procedures in multiple comparisons. Ciência e Agrotecnologia 38:109-112 . doi:10.1590/S1413-70542014000200001.

Gerdemann, J.W., and Nicolson, T.H. 1963. Spores of mycorrhizal Endogone species extracted from soil by wet sieving and decanting. Transactions of the British Mycological Society 46:235-246. doi:10.1016/S0007-1536(63)80079-0.

Giovannetti, M., and Mosse, B. 1980. An evaluation of techniques for measuring vesicular arbuscular mycorrhizal infection in roots. New Phytologist 84:489-500. doi:10.1111/j.1469-8137.1980.tb04556.x.

Goulart, A.M.C. 2008. Aspectos gerais sobre os nematoides das lesões radiculares (gênero Pratylenchus). 30 p. Embrapa Cerrados, Planaltina, Brasília D.F., Brasil.

Grümberg, B.C., Urcelay, C., Shroeder, M.A., Vargas-Gil, S., and Luna, C.M. 2015. The role of inoculum identity in drought stress mitigation by arbuscular mycorrhizal fungi in soybean. Biology and Fertility of Soils 51:1-10. doi:10.1007/s00374-014-0942-7.

Hussey, R.S., and Roncadori, R.W. 1978. Interaction of Pratylenchus brachyurus and Gigaspora margarita on cotton. Journal of Nematology 10:16-20. 
Hussey, R.S., and Roncadori, R.W. 1982. Vesicular-Arbuscular mycorrhizae may limit nematode activity and improve plant growth. Plant Disease 66:9-14.

Inomoto, M.M. 2008. Importância e manejo de Pratylenchus brachyurus. Revista Plantio Direto 108:4-9.

Jansa, J., Smith, F.A., and Smith, S.E. 2008. Are there benefits of simultaneous root colonization by different arbuscular mycorrhizal fungi? New Phytologist 177:779-789. doi:10.1111/j.1469-8137.2007.02294.x.

Jenkins, W.R. 1964. A rapid centrifugal-flotation technique for separating nematodes from soil. Plant Disease Reporter 48:692.

López-Ráez, J.A., Verhage, A., Fernández, I., García, J.M., Azcón-Aguilar, C., Flors, V., et al. 2010. Hormonal and transcriptional profiles highlight common and differential host responses to arbuscular mycorrhizal fungi and the regulation of the oxylipin pathway. Journal of Experimental Botany 61:2589-2601. doi:10.1093/jxb/erq089.

Nair, A., Kolet, S.P., Thulasiram, H.V., and Bhargava, S. 2015. Systemic jasmonic acid modulation in mycorrhizal tomato plants and its role in induced resistance against Alternaria alternata. Plant Biology 17:625-631. doi:10.1111/plb.12277.

Phillips, J.M., and Hayman, D.S. 1970. Improved procedures for clearing roots and staining and vesicular-arbuscular mycorrhizal fungi for rapid assessment of infection. Transactions of the British Mycological Society 55:157-160. doi:10.1016/S0007-1536(70)80110-3.

Pinochet, J., Campubrí, A., Calvet, C., Fernández, C., and Kabana, R.R. 1998. Inducing tolerance to the root-lesion nematode Pratylenchus vulnus by early mycorrhizal inoculation of micropropagated Myrobalan 29 C plum rootstock. Journal of the American Society for Horticultural Science 123:342-347.

Pozo, M.J., and Azcón-Aguilar, C. 2007. Unraveling mycorrhiza-induced resistance. Current Opinion in Plant Biology 10:393398. doi:10.1016/j.pbi.2007.05.004.

Rosseto, P., Urcoviche, R.C., Oliveira, J.R., e Alberton, O. 2012. Densidade de esporos de fungos micorrizicos arbusculares do banco de germoplasma de glomales da Unipar. Arquivos de Ciências Veterinárias e Zoologia da UNIPAR 15:43-47. doi:org/10.25110/arqvet.v15i1.2012.4166.

Schouteden, N., De Waele, D., Panis, B., and Vos, C.M. 2015. Arbuscular mycorrhizal fungi for the biocontrol of plant-parasitic nematodes: a review of the mechanisms involved. Frontiers in Microbiology 6:1-12. doi:10.3389/fmicb.2015.01280.

Sharma, I.P., and Sharma, A.K. 2017. Physiological and biochemical changes in tomato cultivar PT-3 with dual inoculation of mycorrhiza and PGPR against root-knot nematode. Symbiosis 71:175-183. doi:10.1007/s13199-016-0423-x.

Smith, S.E., and Read, D.J. 2008. Mycorrhizal symbiosis. $3^{\text {er }}$ ed. 800 p. Academic Press, London, UK.

Smith, S.E., Smith, F.A., and Jakobsen, I. 2004. Functional diversity in arbuscular mycorrhizal (AM) symbioses: the contribution of the mycorrhizal P uptake pathway is not correlated with mycorrhizal responses in growth or total P uptake. New Phytologist 162:511-524. doi:10.1111/j.1469-8137.2004.01039.x.

Stangarlin, J.R., Kuhn, O.J., Toledo, M.V., Portz, R.L., Schwan-Estrada, K.R.F., e Pascholati, S.F. 2011. A defesa vegetal contra fitopatógenos. Scientia Agraria Paranaensis 10:18-46. doi:10.1818/sap.v10i1.5268.

Taiz, L., e Zeiger, E. 2013. Fisiologia vegetal. 5 ed. 918 p. Artmed, Porto Alegre, Rio Grande do Sul, Brasil.

Talavera, M., Itou, K., and Mizukuno, T. 2001. Reduction of nematode damage by root colonization with arbuscular mycorrhiza (Glomus spp.) in tomato-Meloidogyne incognita (Tylenchida: Meloidogynidae) and carrot-Pratylenchus penetrans (Tylenchida: Pratylenchidae pathosystems). Applied Entomology and Zoology 36:387-392. doi:10.1303/aez.2001.387.

Thaler, J.S., Humphrey, P.T., and Whiteman, N.K. 2012. Evolution of jasmonate and salicylate signal crosstalk. Trends in Plant Science 17:260-270. doi:10.1016/j.tplants.2012.02.010.

Urcoviche, R.C., Castelli, M., Gimenes, R.M.T., and Alberton, O. 2014. Spore density and diversity of arbuscular mycorrhizal fungi in medicinal and seasoning plant. African Journal of Agricultural Research 9:1244-1251. doi.org/10.5897/AJAR2013.8025.

Urcoviche, R.C., Gazim, Z.C., Dragunski, D.C., Barcellos, F.G., and Alberton, O. 2015. Plant growth and essential oil content of Mentha crispa inoculated with arbuscular mycorrhizal fungi under different levels of phosphorus. Industrial Crops and Products 67:103-107. doi.org/10.1016/j.indcrop.2015.01.016.

Veresoglou, S.D., and Rillig, M.C. 2012. Suppression of fungal and nematode plant pathogens through arbuscular mycorrhizal fungi. Biology Letters 8:214-217. doi:10.1098/rsbl.2011.0874.

Vos, C.M., Tesfehun, A.N., Panis, B., Waele, D.D., and Elsen, A. 2012. Arbuscular mycorrhizal fungi induce systemic resistance in tomato against the sedentary nematode Meloidogyne incognita and the migratory nematode Pratylenchus penetrans. Applied Soil Ecology 61:1-6. doi:10.1016/j.apsoil.2012.04.007.

Whipps, J.M. 2004. Prospects and limitations for mycorrhizas in biocontrol of root pathogens. Canadian Journal of Botany 82:1198-1227. doi:10.1139/b04-082. 